\title{
GENDER AND SCHOOL TYPE AS CORRELATES OF CAREER CHOICE AMONG SENIOR SECONDARY SCHOOL ADOLESCENTS IN EGOR LOCAL GOVERNMENT AREA OF EDO STATE, NIGERIA: COUNSELLING IMPLICATION
}

\author{
Martins Noyosase IGBINEWEKA, PhD \\ Counselling Psychologist and Lecturer, Department of Educational Evaluation \\ And Counselling Psychology, Faculty of Education, University of Benin, \\ Benin City, Nigeria. +2348063807911 \\ Corresponding Author \\ $\&$ \\ James Odunayo AGBOOLA, PhD \\ Counselling Psychologist and Lecturer, Department of Education, \\ Faculty of Arts and Education, Benson Idahosa University, \\ Benin City, Nigeria. \\ $+2348148444569 ; 08056736230$
}

https://doi.org/10.37602/IJSSMR.2020.3504

\begin{abstract}
This study investigated sex and school type as correlates of career choice among senior secondary school adolescents in Egor local government area of Edo State, Nigeria. The descriptive survey design with the correlational approach was adopted for the study. Three questions were raised and their corresponding hypotheses formulated. The Population comprised thirteen (13) Senior Secondary Class-one public secondary schools in Egor Local Government Area of Edo State from which eight schools were randomly selected. The instrument titled "Career Interest Survey Questionnaire" (CISQ) developed by Akinade (2019) and modified by the researcher was used for data collection. The instrument was tested for reliability and a Pearson's Product Moment Correlation Coefficient r-value of .78 was obtained. Data were analysed using a combination of Regression Analysis and Fisher-Z. The result indicated that there was no significant relationship between sexes and the career choices of students; there was a relationship between school-type and the career choice of students and finally, that there was a significant difference in the relationship between school type and adolescent career choice by sex. It was the recommended that professional school counsellors should be sent to schools irrespective of school type for support on career guidance as this would help in assessing the needs of adolescents as regards career choices and other aspirations.
\end{abstract}

Keywords: Sex, School Type, Correlates, Career Choice and Adolescents. 


\section{International Journal of Social Sciences and Management Review}

Volume: 03, Issue: 05 “September - October 2020"

ISSN 2582-0176

\subsection{INTRODUCTION}

Choosing a career is not just like picking an orange from a basket. Successful career seldom happens by chance except for a significant few. Career selection is one of the main important choices a student will have to take in his life. This choice of decision will have an impact on them throughout their lives. Career plays a very fundamental and significant role in the life of the individuals because it determines the pattern of their income, affects the individual's personality and concept of life. Therefore, a career is a lifetime pursuit of success. The term career is broadly defined as the roles people play including students, parents, employees, retirees and employers, in securing a livelihood (Eremie \& Okwulehie, 2018). Hewitt (2010), suggested that most people are affected by a career that their parent favours, others flow with the career that their educational choice has opened for them, some choose to follow their passion regardless of how much or little it will make them, while others choose the career that gives high income. Career choice has become a complex science with the advent of information technology, the emergence of post-industrial revolution and job competition. It was a common practice in the old days to find feudalism converting it into a family affair where the son of a blacksmith was destined to become a blacksmith and a feudal was born a leader. According to Eremie \& Okwulehie (2018), industrialization and post-industrialization have made it possible for a common person to be richer as long as they have due skills and knowledge. Today, one does not only need to make due to career planning but also exhaustive career research before making a career choice so as to adjust with the evolving socio-economic conditions (Wattles, 2009).

Consequently, results from several studies had shown that secondary school students all over the world are faced with the dilemma in making career decisions (Issa \& Nwalo 2008; Macgregor, 2007; Watson, McMahon, Foxcroft \& Els, 2010). In Africa, the sources of career decision making challenges among students in secondary schools are majorly inadequate information, ignorance, customs and lack of exposure to career outlets (Austin, 2010; Stikkelorum, 2014). However, based on an exclusive focus on academics, many secondary schools neglect the need for adolescents to acquire greater competence in the knowledge and skills required by them in making informed career decisions (Gati, Krausz \& Osipow, 2006), although, the process of aligning career decision making with educational requirements has increasingly become complex with evolution of advanced technology in the world today than before (Onoyase \& Onoyase, 2009). Even though young people have high ambitions, expecting to be well educated and have professional careers, still, many do not develop coherent plans for achieving their goals (Schneider and Stevenson, 2009). However, with the complexities of unemployment and the technological shifts in today's labour market, young people need not only information but also the skills they can get to ensure they make sound career decisions (Okumu, 2009);

In adolescence, career preparation is an important precursor for successful career development across the life span and is closely related to adolescence adjustment and wellbeing (Skorikov, 2007). People make their choice of career at the adolescent stage which could have impact and consequences on their psychological well-being, future vocation and even health (Scott, Repucci and Woodland, 2005). The Secondary school years present the transition from the cooperatively sheltered life of the primary school to the freedom and responsibility of either tertiary education or employment (Watts \& Kidd 2000). But there are 


\section{International Journal of Social Sciences and Management Review}

many motivational factors that could influence the vocational preference of secondary school adolescents, among them are intellectual abilities, attitudes, family, schooling, personality, sex differences, interest and school location (Nwamuo, 2001).

In Nigeria, one of the factors that could strongly relate to the adolescent's career decision making process is gender. Because of our deeply rooted stereotypes about men and women, gender continues to have a significant impact on the career paths of our sons and daughters. Parental beliefs about scholastic ability and attitudes about performance are some of the most powerful influences. Many still believe that boys are better at math, mechanics, and logical thinking and expect boys to be engineers, doctors, and architects. Girls are expected to be better at verbal skills, intuition and nurturing, so they are expected to be nurses, social workers, or teachers. While all career choices should be equally respected and valued, the fact is, traditional career choices for girls tend to cluster them in lower-paying jobs. Berz (2002) discovered that many females have been socialized to adopt nurturing roles. In the same vein, Durosaro and Adebanke (2012) investigated gender as a factor in the career choice readiness at senior secondary school students in Ilorin, Kwara State. The main findings revealed that male and female secondary school students differ greatly in their career choice readiness. Grayson and Newton (2007) indicated that women valued opportunities to provide comprehensive care when choosing a career speciality more than men. It is believable that societal values and expectation are perceived to have placed a restriction in the kind of career that girls are opportune to choose as this had hindered a lot of girls' career decision-making and consequently led to a wrong career path which invariably lead to confusion, discouragement, dissatisfaction and frustration (Egunjobi, 2006). Ojeda and Flores (2008) and Gati and Saka (2001) stated that male and female students in America perceived similar patterns of influence on their current career expectations. Malubay, Mercado and Emeliza (2015) in the Philippines, found that sex had no influence on career choices. Agarwala (2008) studied the factors that affect career choices in MBA students in India, explored the importance of relationships and their influence on career choices of 93 students. The result showed that gender differences and financial rewards were the most important determinant for a career choice in males while for female participant's skills, competencies and abilities were more important. In Nigeria Otto \& Nkenchor (2010) found that sex had no influence on career choices while Eyo (2011) revealed that sex has a significant influence on the occupation preference among counselled and uncounselled Nigerian students. This implied that, whether the student received counselling or not, gender difference continues to manifest among students.

Another factor that could strongly relate to adolescent's career choice is school type. This factor is of two forms: co-educational (mixed school) and single-sex school. Co-educational refers most generally to education at the elementary, secondary, or postsecondary level in which males and females attend school exclusively with members of opposite sex while single-sex education refers to the school in which males or females attend school exclusively with members of their own sex. The type of school attended by the adolescent could have a significant impact on the career development of the individual. Adolescents learn which careers are "acceptable" from their social environment (Schoon, 2001). However, it has been discovered that the confidence level of students varies depending on the type of school attended. Halpern (2007) posited that mixed schools are not doing enough to promote girls' confidence and ambitions, while single-sex schools find it easier to promote confidence and 


\section{International Journal of Social Sciences and Management Review}

competitive attitude in the absence of boys which may influence their decision to choose 'more robust careers' such as engineering and medicine. He further opined that boys in allmale educational environments feel more comfortable to pursue 'arts' degrees compared with boys in mixed schools.

Considering the fact that, even though, the adolescent stage is known to be a period of storm and stress, still, they have to make their respective career decisions and if studies have shown that this national posterity is facing difficulties in selecting their appropriate career thereby falling short of maximum achievement of their potentials, it is imperative to investigate the salient factors that could be responsible for this anomaly. This is why the researchers sought to investigate if sex and school type relate to career choice among senior secondary school adolescents in Egor local government area of Edo State since there seems to be a dearth in the literature regarding the aforementioned topic and the results of this study would be a useful guide to counselling psychologists, career guidance officers and experts, in assisting their clients towards making appropriate career choices.

\subsection{PURPOSE OF THE STUDY}

The purpose of this study is to investigate sex and school type as correlates of career choice among senior secondary school adolescents in Egor local government area of Edo state.

\subsection{Research Questions}

1. Is there any relationship between sex and adolescents career choice?

2. Is there any relationship between school type and adolescents career choice?

3. Is there any difference in the relationship between school type and adolescents' career choice by sex?

\subsection{Hypotheses}

Three research questions were hypothesised;

1. There will be no significant relationship between sex and adolescents career choice.

2. There will be no significant between school type and adolescents career choice

3. There will be no significant relationship between school type and adolescents' career choice based sex.

\subsection{METHODOLOGY}

The correlational survey design was adopted for this study. The population of the study consisted of two thousand two hundred and seventy (2270) SS1 students from the 12 public secondary schools in Egor Local Government Area of Edo State.

Table 1: Population Public Senior Secondary Schools Class Two Students in Egor Local Government Area of Edo State 


\section{International Journal of Social Sciences and Management Review}

\begin{tabular}{ccccc}
\hline Schools & School Type & Male & Female & Total \\
\hline A & Co-educational & 199 & 201 & $\mathbf{4 0 0}$ \\
B & Single Girls & 182 & - & $\mathbf{1 8 2}$ \\
C & Co-educational & 210 & 186 & $\mathbf{3 9 6}$ \\
D & Co-educational & 40 & 30 & $\mathbf{7 0}$ \\
E & Co-educational & 102 & 68 & $\mathbf{1 7 0}$ \\
F & Co-educational & 106 & 131 & $\mathbf{2 3 7}$ \\
G & Single Boys & - & 162 & $\mathbf{1 6 2}$ \\
H & Co-educational & 26 & 26 & $\mathbf{5 2}$ \\
I & Co-educational & 34 & 44 & $\mathbf{7 8}$ \\
J & Co-educational & 61 & 50 & $\mathbf{1 1 1}$ \\
K & Co-educational & 124 & 152 & $\mathbf{2 7 6}$ \\
L & Co-educational & 58 & 78 & $\mathbf{1 3 6}$ \\
TOTAL & & 1,142 & 1,128 & $\mathbf{2 , 2 7 0}$ \\
\hline
\end{tabular}

Source $=$ Ministry of Education, Iyaro-Benin City, (2019).

Table 2: Sample of Public Senior Secondary School Class Two Students from Eight Selected Schools in Egor Local Government Area of Edo State

\begin{tabular}{llcc}
\hline S/N & \multicolumn{1}{c}{ Schools } & Male & Female \\
\hline 1. & Asoro Grammar School & 25 & 25 \\
2. & Edo Boys High School & 50 & - \\
3. & Uselu Secondary school & 25 & 25 \\
4. & Iyoba College & - & 50 \\
5. & Uwelu Secondary School & 25 & 25 \\
6. & Evboutubu Secondary School & 25 & 25 \\
7. & Ohonre Secondary School & 25 & 25 \\
8. & Egor Secondary School & 25 & 25 \\
& TOTAL & 200 & 200
\end{tabular}

Table 2 shows the sample of students randomly selected from eight schools in Egor Local Government Area of Edo State. The sample size for this study consists of four hundred (400) SS1 students drawn from eight (8) public secondary schools in Egor Local Government Area of Edo State. This study adopted a multi-stage sampling technique. Firstly, the stratified 


\section{International Journal of Social Sciences and Management Review}

sampling technique was used to stratify the schools into single-sex, mixed, urban and rural schools. Secondly, two schools were randomly selected from each stratum using balloting without replacement. Lastly, fifty (50) students were randomly selected each from the selected schools. However, 371 respondents were used for analysis, while 29 questionnaires were rejected because they were not properly filled.

The instrument for this study was a questionnaire titled 'Career Choice Questionnaire' (CCQ) adapted from Akinade (2019) Vocational Interest Survey and modified by the researcher. This instrument was made up of two sections, section A and B. Section A contains information about students bio-data while section B consists of thirty (30) items on a fourpoint Likert Scale of strongly agree (SA), Agree (A), disagree (D) and strongly disagree (SD). To ascertain the validity of the instrument, the research instrument was subjected to both face and content validation through a series of amendments made by experts in the field of Counselling Psychology and one from Measurement and Evaluation. The Pearson's Product Moment Correlation Coefficient ( $r$ ) was used to determine the reliability consistency between a set of scores gotten from twenty students who were not part of the sample and an rvalue of .78 was obtained, indicating that the instrument was highly consistent and reliable. The hypotheses one and two were analysed using Regression Analysis while hypotheses 3 was analysed using Fisher-Z.

\subsection{RESULT}

H01: There will be no significant relationship between sex and adolescents career choice.

Table 3: Relationship between Sex and Adolescent Career Choice

\begin{tabular}{ccccc}
\hline Variables & $\mathrm{N}$ & $\mathrm{R}$ & $\mathrm{p}$-value & Remarks \\
\hline $\begin{array}{c}\text { Sex and } \\
\text { Career Choice }\end{array}$ & 371 & .033 & .193 & Not \\
& & & & Significant
\end{tabular}

Table 3 shows the relationship between sex and adolescent career choice. From the table the correlation coefficient $(r)=.033$, this is an indication of a positive relationship between sex and adolescent career choice. The correlation coefficient though is not significant, testing at .05 alpha level because the p-value of .193 is greater than .05 . Therefore the null hypothesis that says there is no significant relationship between sex and adolescent career choice is hereby retained.

H02: There will be no significant between school type and adolescents career choice

Table 4: Relationship between school type and adolescent career choice

$\begin{array}{lllll}\text { Variables } & N & R & p \text {-value } & \text { Remarks }\end{array}$

School Type 


\section{International Journal of Social Sciences and Management Review}

and

371

.040

.034

Significant

Career Choice.

Table 4 shows the relationship between school type and adolescent career choice. From the table the correlation coefficient $(r)=.040$, this is an indication of a positive relationship between school type and adolescent career choice. The correlation coefficient is significant, testing at .05 alpha level because the p-value of .034 is less than .05 . Therefore the null hypothesis that says there is no significant relationship between school type and adolescent career choice is hereby rejected, meaning that there is a relationship between school-type and the career choice of students.

H03: There will be no significant relationship between school type and adolescents' career choice based on sex.

Table 5: Difference in the Relationship between School Type and Adolescent Career Choice by Sex

\begin{tabular}{ccccccccc}
\hline \multicolumn{7}{c}{ Males } & \multicolumn{7}{c}{ Females } \\
\hline $\mathrm{N}$ & $\mathrm{R}$ & $\mathrm{Zr}$ & $\mathrm{N}$ & $\mathrm{R}$ & $\mathrm{zr}$ & z-cal & z-cri & Remarks \\
167 & .027 & .03 & 154 & .049 & .05 & 0.18 & 1.96 & $\mathrm{NS}$ \\
\hline
\end{tabular}

NS= Not Significant

Table 5 shows the relationship between school type and adolescent career choice based on sex. Males $(\mathrm{N}=167, \mathrm{r}=.027$ and $\mathrm{Zr}=.03)$, Females $(\mathrm{N}=154, \mathrm{r}=.049$ and $\mathrm{Zr}=.05)$. The computed $\mathrm{z}$-value $(\mathrm{z}$-cal $)=0.18$ while the table $\mathrm{z}$-value $(\mathrm{z}$-cri. $)=1.96$. Since the computed $\mathrm{z}$ value falls within the acceptance region of the standard normal curve, the null hypothesis that says there is no significant difference in the relationship between school type and adolescent career choice based on sex is therefore retained.

\subsection{DISCUSSION}

The result of the study reveals that there was no significant relationship between sex and adolescent career choice. This assertion lends credence to the findings of Ojeda and Flores (2008) and Gati and Saka (2001) who stated that male and female students in America perceived similar patterns of influence on their current career expectations; Malubay, Mercado and Emeliza (2015) in the Philippines and in Nigeria Ottu \& Nkenchor (2010) that found that gender has no influence on career choices. However, contrary to the aforementioned finding Agarwala (2008) in India found that gender differences and financial rewards were the most important determinants for a career choice in males while for female participant's skills, competencies and abilities were more important. Also in Nigeria, where Eyo (2011) revealed that gender has a significant influence on the occupation preference among counselled and uncounselled Nigerian students regardless of whether the student received counselling or not, the gender influence continues to manifest in students. 


\section{International Journal of Social Sciences and Management Review}

It was also discovered that there was a significant relationship between school-type and the career choice of students. The finding lends credence to the assertion made by Schoon (2001) who posited that the type of school attended by the adolescent could have a significant impact on the career development of the individual and this corroborates Halpern (2007) who posited that mixed schools are not doing enough to promote girls' confidence and ambitions, while single-sex schools find it easier to promote confidence and competitive attitude in the absence of boys which may influence their decision to choose 'more robust careers' such as engineering and medicine.

In the present study, it was also observed that there was no significant relationship between school type and adolescent career choice based on sex. This finding is in support to the research carried out in Busia County, Kenya by Ogutu, modern and maria (2017) who found that sex and the school type attended had an influence on career choice.

\subsection{CONCLUSION}

From the result of the study, it was concluded that there was no significant relationship between sexes and the career choice of students and that there was a significant relationship between school-type and the career choice of students and finally, that there was a significant relationship between school type and adolescent career choice based on sex.

\subsection{RECOMMENDATION}

Based on the findings of this study, therefore, it is recommended that:

1. Professional school counsellors should beckon to schools irrespective of school type for support on career guidance as this would help in assessing the needs of adolescents as regards career choices and other aspirations.

2. School counsellors should be assisted by school administrators to provide opportunities that would nurture interests in the vocational subject matter by creating an enhanced environment that would nurture the discovery of aptitudes for vocational content among students irrespective of their sexes.

3. Government and policymakers should from time to time enforce the implementations of policies that would enhance career guidance in schools and promote activities of career guidance counsellors and elimination of counsellors teaching in the classroom.

4. The government should use this information as a springboard to achieve a balance in the distribution of trained Counselling psychologist to schools so as to look into the pattern of career aspirations of our young ones who constitute tomorrow's workforce as failure to do so may lead to the wrong choice on the part of the students.

\section{Implication for Counselling}

Based on the findings of this study, the counsellors should do the following;

1. The school proprietors, principals and teachers need to be sensitised on the functions and benefits of the school guidance counsellor, so as to aid early referral for students observed to have difficulties in making a career choice. 


\section{International Journal of Social Sciences and Management Review}

Volume: 03, Issue: 05 “September - October 2020"

ISSN 2582-0176

2. Ensure students cultivate reading habits and provide current and adequate information about the knowledge of the world of work to the students.

3. Counsellors need to frequently update themselves by attending seminars, workshop and conferences that will equip them about requisite and up to date vocational making therapies that promote career choice.

\section{REFERENCES}

Agarwala, T. (2008). Factors influencing career choice of management students in India. Career Development International, 13(4):362-376.

Austin, C.Y. (2010). Perceived factors that influence career decision self-efficacy and engineering related goal intentions of African American high school students. Career

and Technical Education Research, 35,119-135.

Betz, N.E, (2002). The relationship of career-related self-efficacy expectations to perceived career options in college women and men. Journal of counselling psychology, 28(5), $399-410$

Durosaro, I. \& Adebanke, N.M. (2012). Gender as a factor in the career choice readiness of senior secondary school students in Metropolis of Kwara state Nigeria. International Journal of Humanist and Social Science, 2(14):109-113.

Egunjobi C.G (2006). Child Rearing Patterns and Career choice among Secondary School students. Empirical evidence from Rivers State of Nigeria. Journal of sustainable development in Africa 9 (2), 17-29

Eremie, M. \& Okwulehie, C. 2018). Factors Affecting Career Choice among Senior Secondary School Students in Obio/Akpor Local Government Area of Rivers State (Implication to Counselling). International Journal of Innovative Education Research 6(2):27-39

Eyo, M.B. (2011). Gender and occupational preferences among senior high school students in Cross River State Nigeria. An International Multidisciplinary Journal Ethiopia, $5(1): 327$ 341.

Gati, I. \& Saka, N. (2001). High school students' career-related decision making difficulties. Journal of Counselling Development, 79(3): Summer:331-340.

Gati, I., Krausz, M., \& Osipow, S. H. (2006). A taxonomy of difficulties in career decision making. Journal of Counseling Psychology, 43, 510-526.

Gray son, M. S., \& Newton, D. A. (2007). Gender differences in career choice influences. Paper presented at the 22nd Annual Meeting of the Society for Industrial and Organizational Psychology, 


\section{International Journal of Social Sciences and Management Review}

Volume: 03, Issue: 05 “September - October 2020"

ISSN 2582-0176

Halpern, D. F. (2007). The science of sex differences in science and mathematics. Psychological Science in the Public Interest, 8, 1-51. doi:10.1111/j.15291006.2007.00032.x.

Hewitt, J. (2010). Factors influencing career choice. Cited from www.ehow.com on $15 / 02 / 2020$.

Issa, A.O. \& Nwalo, K. (2008). Factors Affecting the Career Choice of Undergraduates in Nigerian Library and Information Science Schools. African Journal of Library, Archives and Information Science. From http://findarticles.com/p/articles_ 700 $2118 /$ ai n2 $8539226 /$ tag= content; coll (Retrieved on 12 October 2011)

Macgregor, K. (2007). South Africa: Student Dropout Rates Alarming in SA Universities. From <http://wwwuniversity worldnews.com/ article. php? Story 2007102510251 $0224538 \quad 0>$ (Retrieved on 23 November 2011 ).

Malubay, G.J.J., Mercado, K.A.O. \& Emeliza, M. (2015). Factors affecting the decision of freshmen students in pursuing hospitality and tourism programs in Lyceum of the Philippines University-Laguna: Basis for enhancement. LPU-Laguna Journal of International Tourism and Hospitality Management, 3(1):23-48.

Obimba M (2017).“ Effect of parental socio-economic status on parental care and social adjustment in the UBE programme," the Implication for counseling. Int. J. Educ. Res. $3(2): 82-87$.

Ogutu. J.P, Odera, P. \& Maragia, S.N (2017). Self-Efficacy as a Predictor of Career Decision Making Among Secondary School Students in Busia County, Kenya. Journal of Education and Practice, Vol.8, No.11, 2017. ISSN 2222-1735 (Paper) accessed on www.iiste.org ISSN 2222-288X (Online)

Okumu, J. (2009). Foreword In: Gitonga, C. A systematic guide to career choice. Nairobi: Intergrity.

Onoyase, D. and Onoyase, A. (2009). The relationship between personality and career Choice of secondary students in Federal government colleges in Nigeria. Nabraska: Delta State University Nigeria

Ottu, I.F.A. \& Nkenchor, C.T. (2010). Gender and leadership style as socio demographic indicators of job satisfaction in AKWA Ibom State Civil Service. Gender and Behaviour, 8(2):3008.

Schoon, I. (2001). Teenage job aspirations and career attainment in adulthood: A 17-year follow-up study of teenagers who aspired to become scientists, health professionals, or engineers. International Journal of Behavioral Development, 25, 124-132. 


\section{International Journal of Social Sciences and Management Review}

Scott, J.M., Repucci, J.H. \& Woodland, S. (2005). Distinguishing the factors influencing college students' choice of major. College Student Journal, 42(2):381-394.

Stikkelorum, M. (2014). What factors influence Young Age Career Decision Making (working paper) Master of Training \& Development, spec. Professional Development. Retrieved from https://www.linkedin.com/pulse7014072519062560138266 on 24th February,2016

Watson, M., McMahon, M., Foxcrof, C., \& Els, C (2010). Occupational aspirations of low socio economic Black South African children. Journal of Career Development, 37(4): 717-734

Watts, A.G. \& Kidd, J.M. (2000). Guidance in the United Kingdom: Past, present and future. British Journal of Guidance and Counselling, 28:485-502.

Wattles, D. W. (2009). The science of getting rich.www.thescienceofgettingrich.net/. 